J. Perinat. Med. $8(1980) 27$
Risks occurring in birth induction without considering cervix maturity

\author{
K. Goeschen, S. Pakzad
}

Unit of Perinatal Medicine - The Free University of Berlin
In $1964 \mathrm{E}$. H. BisHOP first described a portio index (pelvic score) which stated the birth tendency of the portio in the last weeks of pregnancy and which permitted a prognosis of the course of the birth [1]. In 1973 U. MENNEKING [10] put the prognostic value of the pelvic score for the success of an induced birth in the sense of a scheduled delivery to the test, with the help of a modified results pattern. It was necessary to take into account the different portio results at the beginning of the birth in patients giving birth for the first time and those having given birth before, since the portio of those having given birth before must be considered differently as a result of the changes during the previous pregnancy. Various authors have since then confirmed $[2,3,5,8$ etc.] by their own examinations the importance of cervix maturity for a successful birth induction. Lately however some obstetricians have given the pelvic score less value. JUNG [7] argues, that a woman who has already given birth before should not expect any difficulties from the cervix. MUT KE [11] is of the opinion, that the size and maturity of the infant and not the birth tendency of the portio should determine the moment of induction in women having already given birth before.

These recommendations clearly contradict our own experience drawn from 2000 birth inductions. The purpose of this study therefore is to prove by means of a prospective series of examinations, whether a dependence between the length of the birth and the pelvic score in women having already given birth can be statistically established. In this

\section{Curriculum vitae}

K. GOESCHEN was born in 1948 at Kiel (Germany) and studied medicine at the University of Kiel and Lübeck from 1966 to 1972. He received his obstetrical and gynecological training at the Martin-Luther-Hospital Berlin (M.S. Prof. Dr. G. MARTIUS/. Since Febr. 1979 he is holding the po. sition of Assistant Professor at the Free University of Berlin Department Unit of Perinatal Medicine (M.S. Prof. Dr. E. SALING).

study all patients are registered who had a scheduled delivery or a medically indicated induction at MARTIN-Luther Hospital in Berlin during the period January 1 st, 1976 to March 31 st, 1978.

1315 patients could be considered for the statistical evaluation after deducting those births with spontaneous start of labor; this figure was compiled of 680 first-births and 635 second or more births.

The cervix maturity was estimated always by the same examiner prospectively before each induction. In the first place the birth tendency of the portio was established by means of the modified results pattern after MENNEKING [10] in 516 first births and 453 second or more births. In a second study, which covers 164 first births and 182 second or more births, another pelvic score was used which allowed a finer graduation of the single parameters (Tabs. I and II). The method of induction was the 
Tab. I. Portioindex according to MENNEKING [10] .

\begin{tabular}{llllll}
\hline & POSITION & EFFACEMENT & CONSISTENCY & DILATATION & STATION \\
\hline 1 & posterior & $2 \mathrm{cms}$ & rough & closed & -4 \\
2 & near leading line & $1 \mathrm{~cm}$ & medium & $1-2 \mathrm{cms}$ & -2 \\
3 & in leading line & flat & soft & $2-3 \mathrm{cms}$ & 0 \\
\hline
\end{tabular}

Per each single parameter 1-3 points are possible altogether a total of 15 points can be reached.

Tab. II. Modified portio-score with finely graduated progression.

\begin{tabular}{llllll}
\hline & POSITION & EFFACEMENT & CONSISTENCY & DILATATION & STATION \\
\hline 0,5 & $\begin{array}{l}\text { not available } \\
\text { posterior }\end{array}$ & $2-3 \mathrm{cms}$ & $\begin{array}{l}\text { rigid, tissue-rich } \\
\text { and firmly closed }\end{array}$ & firmly closed & $\begin{array}{l}\text { flexible } \\
\text { difficult to achieve }\end{array}$ \\
1 & $2 \mathrm{cms}$ & rigid, tissue-rich & $\begin{array}{l}\text { pencil-wide } \\
\text { opening }\end{array}$ & -4 \\
1,5 & posterior & $1 \mathrm{~cm}$ & rigid, poor in tissue & just finger wide & -3 \\
1 & near leading line & $0,5-1 \mathrm{~cm}$ & middle-soft & $\begin{array}{l}\text { finger-wide } \\
\text { opening }\end{array}$ & $\begin{array}{l}-3 \\
\text { not shift-able }\end{array}$ \\
2 & $\begin{array}{l}\text { in the leading line } \\
\text { in the leading } \\
\text { line lying close to } \\
\text { dilatation }\end{array}$ & $\begin{array}{l}\text { expired } \\
\text { completely }\end{array}$ & soft & $2-3 \mathrm{cms}$ & -2 \\
3 & very soft & $3 \mathrm{cms}$ and more & 0 \\
\hline
\end{tabular}

For each single parameter a possible $0,5-3$ points altogether a total of 15 points can be reached

same in all patients. The induction of labour was achieved by means of oxytoxin infusion. The immediately following artificial rupture of the membranes was combined with paracervical or epidural anaesthesia to prevent spasmodic retraction disturbances.

\section{Results}

\subsection{Pelvic Score and duration of the birth}

In order to test whether there is a correlation between the duration of the birth and the pelvic score, the above mentioned modified results pattern according to MENNEKING [10] was estimated before the induction of the birth in 516 first births and 453 second or more births prospectively, and then retrospectively in relation to the duration of the birth. The statistical accuracy was achieved through the calculation of the correlation coeffi- cient $r$, which gives the intensity of the connection between two signs, so for example the pelvic score and the duration of the birth. If there is a strongly linear correlation, then the correlation co-efficient picks up its highest possible value of +1 or, when the signs correlate in opposite directions, of -1 . According to this estimation a value of $r=-0.97$ was achieved for first bearers, and for those having given birth before $r=-0.95$. Therefore between the proven measured values there exists a large negative correlation within the given variations (Fig. 1). Therefore with the increasing number of points on the pelvic score, the duration of the birth diminishes continuously, even in first-births and also in second or more births.

This very narrow relationship should emerge even more clearly after a further division of the result patterns, which permits a finer graduation of the single parameters. Thereby in a second study of 164 first and 182 second or more births, we judge 


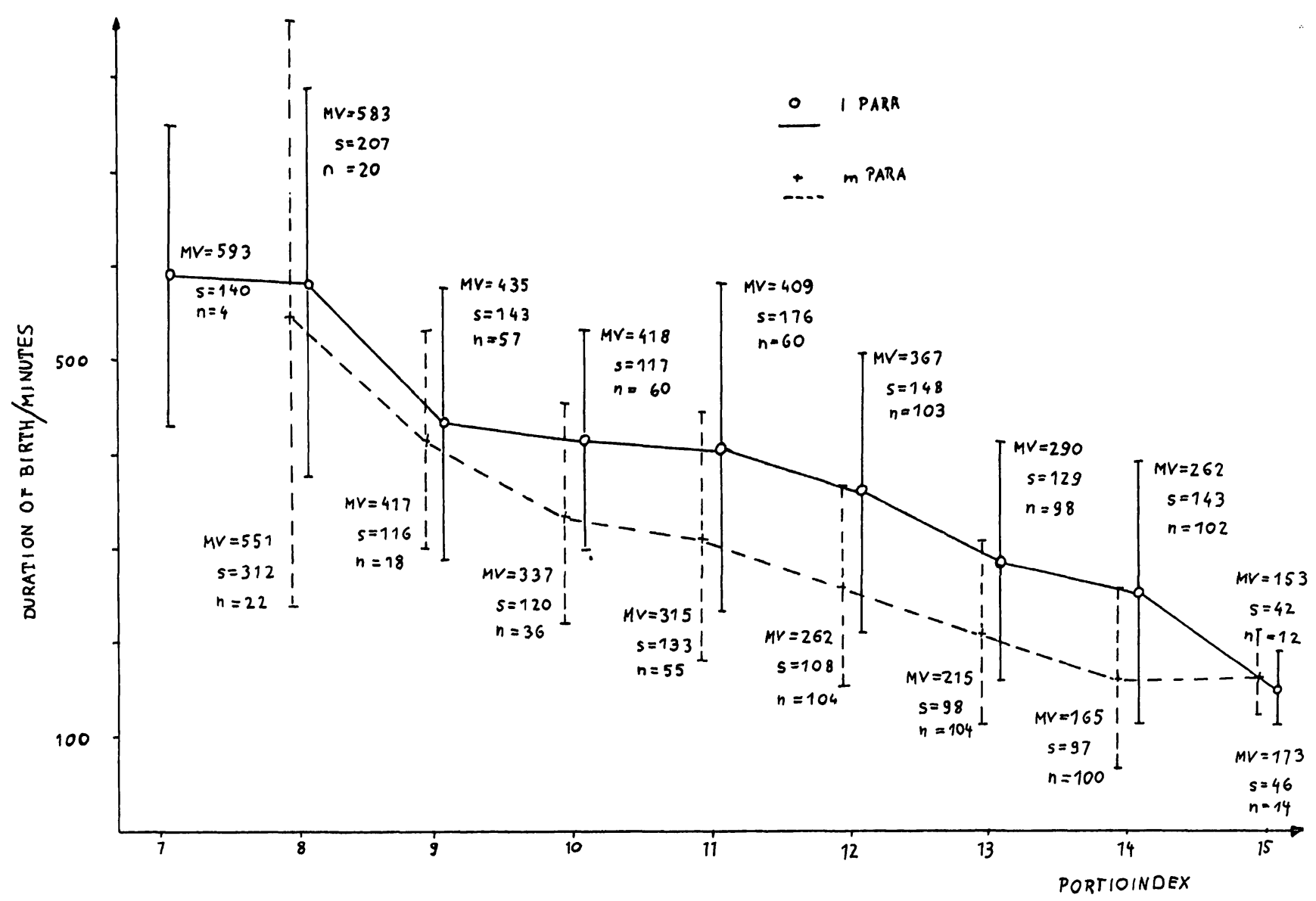

Fig. 1. Relationship between portioindex according to MENNEKING and the duration of the birth ( $\mathrm{n}=516$ first bearers and 453 having given birth before). A strong negative correlation emerged between the values measured. A value of $-0,97$ was calculated for the co-efficient correlation $r$ for the first bearers, and of $-0,95$ for those having given birth before.

the pelvic score on a finer score, which contained 6 graduated possibilities instead of 3 as previously (Tab. II). Hereby a number of points was reached between 2.5 and 15 . In the correlation calculation the finer graduation brought about an even narrower relationship between duration of the birth and portio maturity, and that particularly in second or more births; that is to say in patients having given birth before, the reduction in birth duration with increased pelvic score was even more pronounced as it reached an $r$ level of -0.9933 . In the first bearing patients $r$ was equal to -0.9794 . In this procedure the single parameter points could be estimated accurately through a linear regression, that is a straight line (Fig. 2). The rise $b$ in the regression line can be calculated with the help of a regression equation and can be included in the straight equation as $y=b x+a$. In first-bearers, $b$ then has $a$ value of -119.74 and $a=1729.56$; in second or more bearers bis -92.9 and $a=1316.67$.

\subsection{Duration of the birth and single parameter of} the pelvic score

In order to determine whether a particular parameter of the pelvic score has a special influence on the duration of the birth, that is for example the position of the portio, the effacement, the consistency, the dilatation or the station of the infant's head; all these are singly correlated with the duration of the birth. The statistical estimation with the help of correlation calculation was only carried out on patients having given birth before. A clear correlation emerged between the single parameters and the duration of the birth. In particular the dilatation of the cervix ascertained at the induction proved to be a prognostically expressive criterion for the expected duration of the birth; the parameter station of the presenting part however did not show the slightest correlation. It was interesting to see whether this result was 


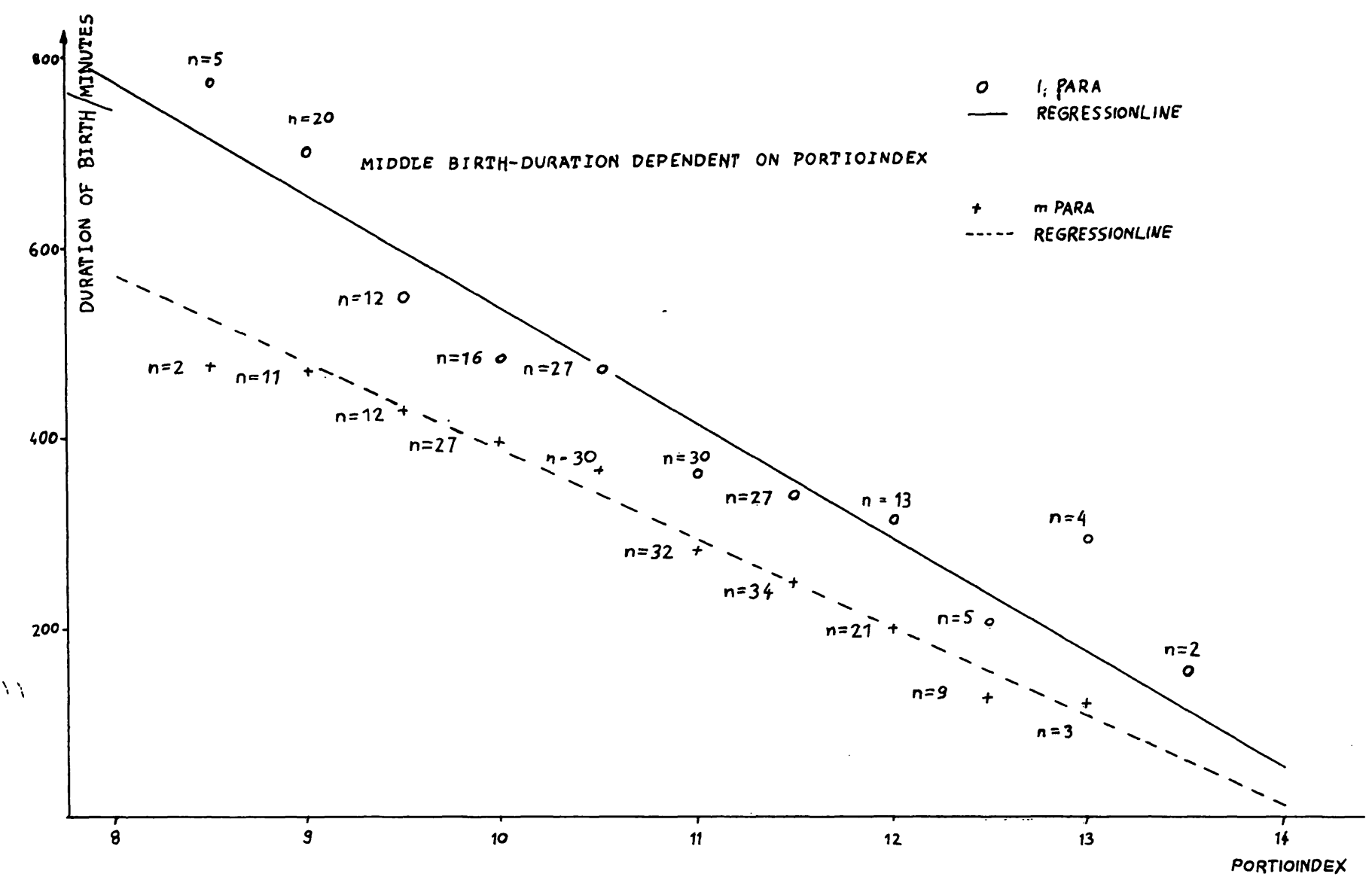

Fig. 2. Relationship between the refined portioindex and the duration of the birth. The points 0 and + represent the median values of the birth-duration to each portio-index. $n$ is given. A value of $r=-0,9794$ was calculated for firstbearers and $r=-0,9933$ for those having given birth before. The relevant regression lines run:

First-bearers $b=-119,47$ and $a=1729,56$, Having given birth before $b=-92,9$ and $a=1316,67$.

also established when calculating the percentual deviations of the partial evidence from the theoretical median value of the basic entirety.

The actual deviations of the single parameters from the expected value were calculated with the aid of the Chi-Quadrate test. As can be seen from Fig. 3 significant deviations of the dilatation of the cervix occurred and also for the presenting part; indeed the deviations for the dilatation lay symmetrically above and in the presenting part symmetrically below the expected value. These calculations prove beyond doubt that the dilatation of the cervix influences the whole pelvic score overproportionally, and the station of the presenting part underproportionally.

\subsection{Distribution of the portio indices}

The strong negative correlation between pelvic score and duration of the birth can be a function of a particular induction selection or a generally accepted fact. To clarify this point the frequency distribution was given in our collective, composed of biologically normal patients, and the result was given in the form of histograms (Figs. $4 \mathrm{a}+\mathrm{b}$ ). In first-bearers and in those having given birth before with an excess probability of $50 \%$, there was a good adjustment according to Lienert to a "normal" or GAuss distribution. So it can be assumed that the strong negative correlation between pelvic score and duration of the birth is a generally accepted fact and is not a function of a particular induction selection.

\subsection{Type of delivery and pelvic score}

In this connection it was of interest to know whether a dependency could also be established between the maturity of the portio. and the opera- 

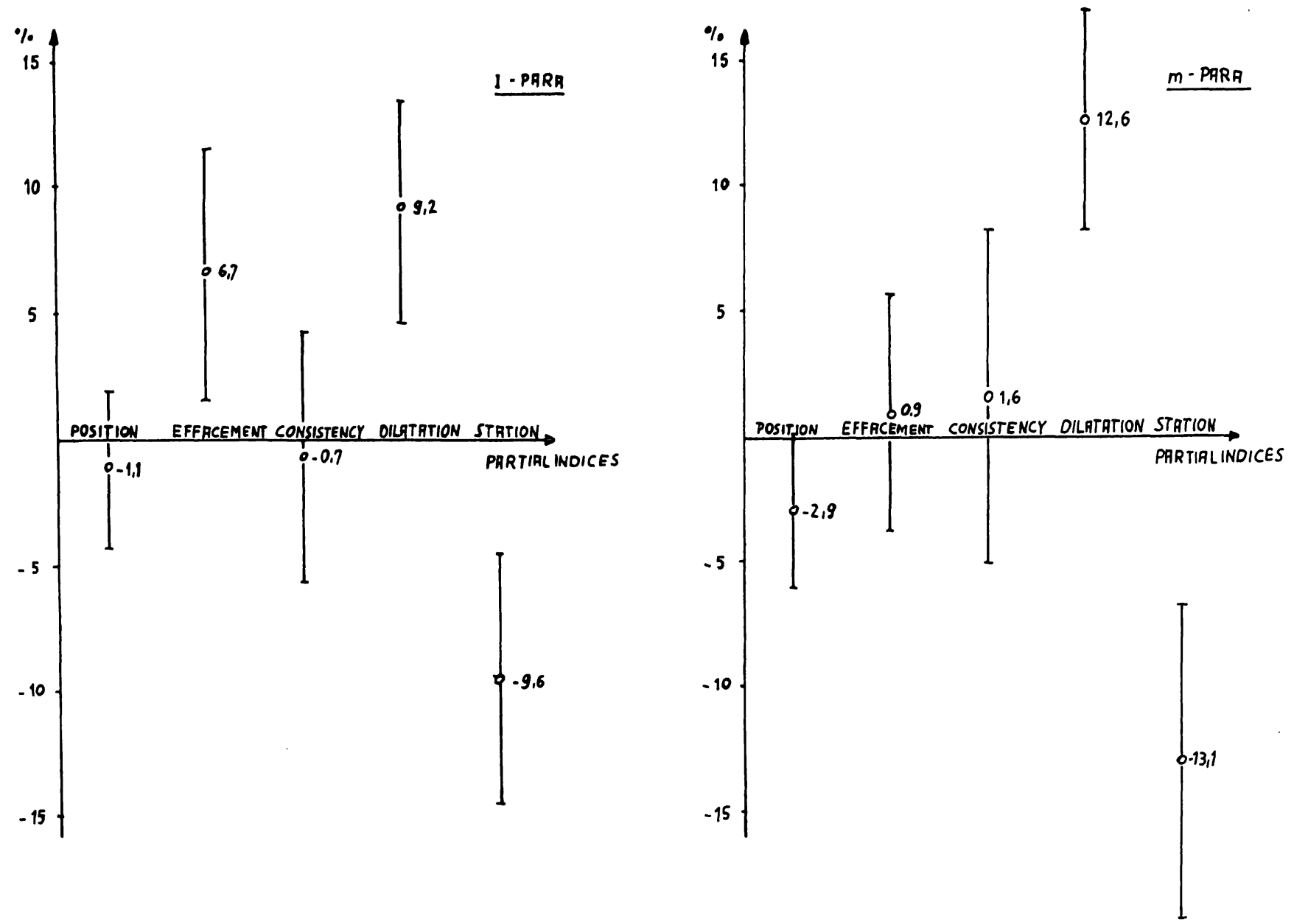

Fig. 3. Relative deviation of the partial indices of the portioindex from the theoretical median value of the basic entirety. Significant deviations of the values of breadth of os uteri and height level at a discrepancy probability of $5 \%$. The values for the os uteri lie symmetrically above the expected level and those of the height level symmetrically below the expected level.

tion frequency. For this the pelvic score modified qualitatively according to MENNEKING [10] was divided into 3 groups (immature $\leqslant 8$ points $=$ group $1 ;$ semi-mature $=9-11$ points $=$ group 2 ; mature $\geqslant 12$ points = group 3 ); and then the frequency of operative deliveries in the three groups was given. The group evaluated was composed of 453 patients who had given birth before; of these 40 patients had an immature pelvic score, 217 had a semi-mature one, and 196 had a mature score. In the first group of 40 patients, $27(67.5 \%)$ were delivered operatively; of these $20(74.1 \%)$ were caesareans, and $7(25.9 \%)$ vacuum extractions. In the second group there were $69(31.8 \%)$ operative deliveries; 23 (33.3\%) were caesareans, and $46(66.7 \%)$ vacuum extractions. In the group of patients having mature cervix it was only necessary to operate in 48 cases $(24.4 \%) ; 1$ of these was a caesarean $(2.8 \%)$, and the other $47(97.2 \%)$ were vacuum extractions (Tab. III).

This result clearly shows that the number of operative deliveries, particularly caesareans, diminishes in accordance with increased birth-tendendy of the portio.

\subsection{The condition of infants post partum and the} pelvic score

In order to see if the cervix maturity influences the APGAR and $\mathrm{pH}$ values of the infants from the above mentioned groups (Tab. III) were compared against each other. In group 1 (immature cervix) there was a 1-minute Apgar-score between 5 and 7 in 5\%; in group 2 (semi-mature cervix) in $2.3 \%$ and in group 3 (mature cervix) in $1.5 \%$. All other infants 


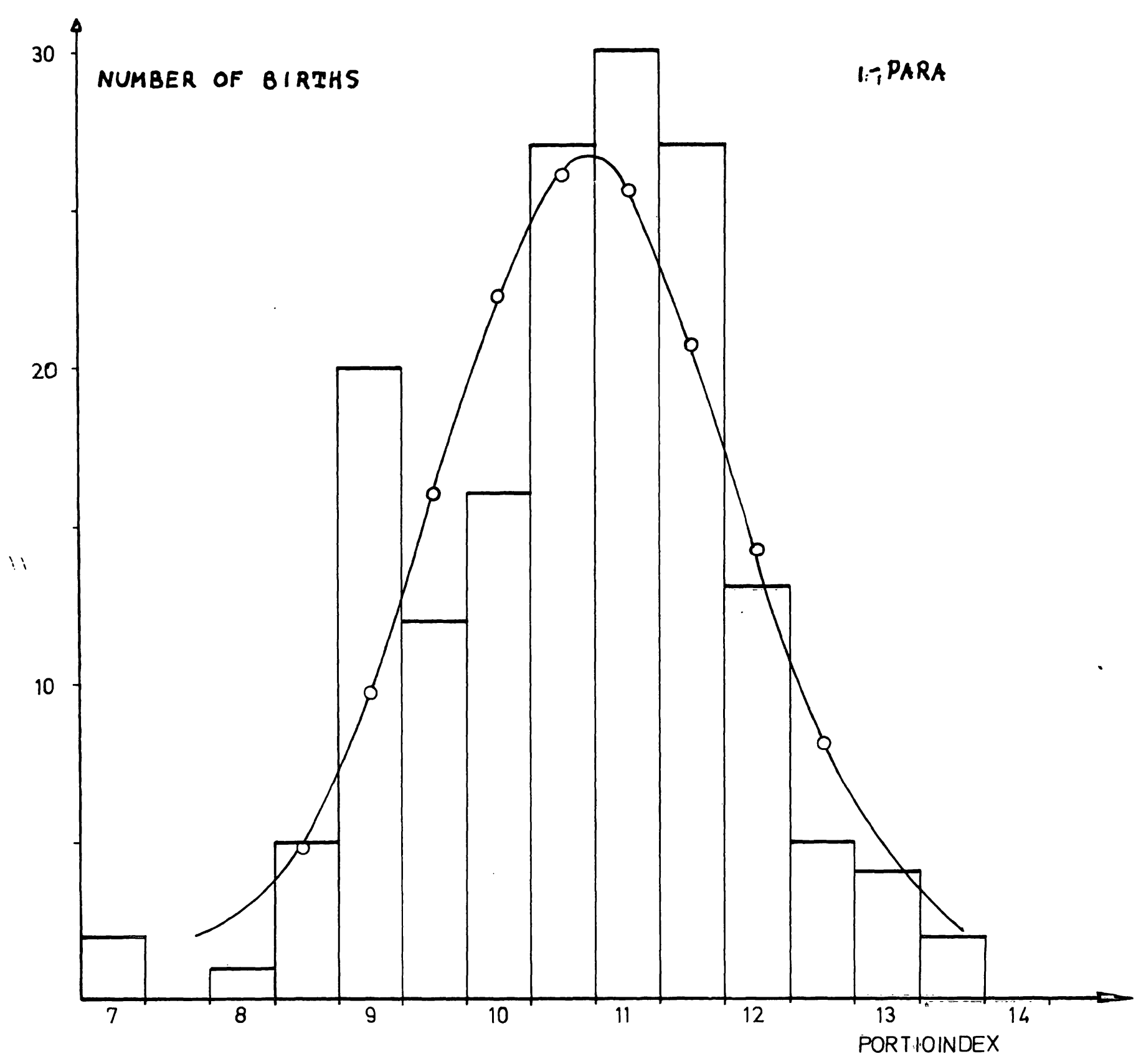

Fig. 4a

had a 1 minute APGAR-Score of $=8$. The 5 minute APGAR scores were normal in all infants (Tab. IV). A similar tendency emerged from the evaluation of the $\mathrm{pH}_{\mathrm{NA}}$-values. Severe acidosis $(\mathrm{pH} 7,1)$ was not observed in any of the 3 groups. In group 1, 2 infants (5.2\%) had moderate acidosis and $12(41.3 \%)$ had slight acidosis. 15 infants $(53.5 \%)$ were born with a normal acid-base status. In group 2, $52(26.3 \%)$ infants were registered with slight acidosis, and $73.7 \%$ with normal $\mathrm{pH}$ values. In group 3,40 $(22.9 \%)$ infants were slightly acidotic and 134 (77.1\%) were normal.

In spite of the small number of cases studied, the tendency is nevertheless clear from the results, that the infants from group 3 (induction with mature cervix) had the best APGAR and $\mathrm{pH}$ values. 


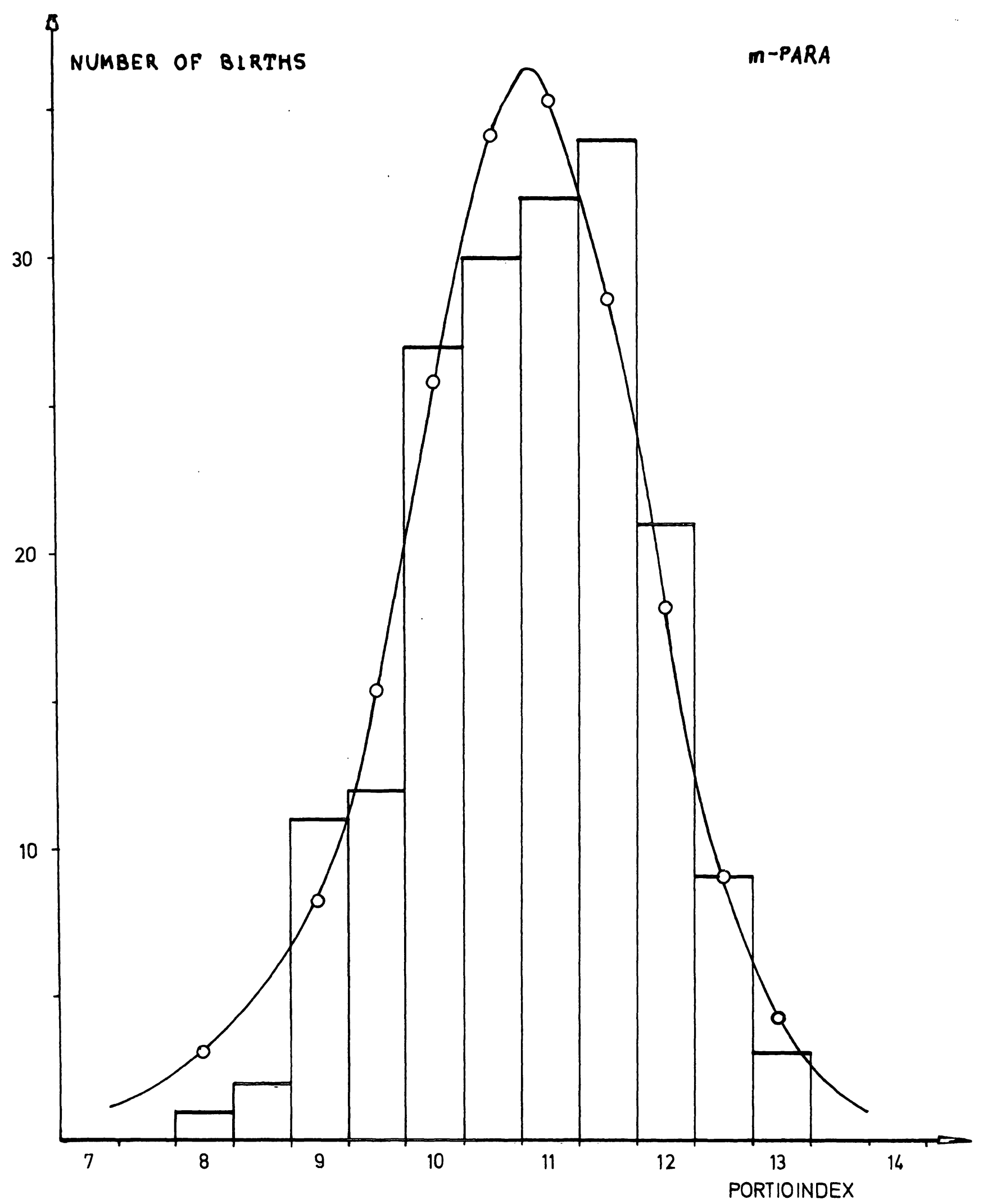

Fig. 4b

Figs. $4 \mathrm{a}+4 \mathrm{~b}$. Frequency distribution of the portioindices. The excess probability according to the Chi-Quadrat Test in first-bearers and those having given birth before was $50 \%$; according to LIENERT a good adjustment to a GAUSS distribution exists.

J. Perinat. Med. 8 (1980) 
Tab. III. Portio index in maturity groups and frequency of operation.

\begin{tabular}{|c|c|}
\hline Portio-maturity & Frequency of operation \\
\hline $\begin{aligned} \text { immature } & \leqslant 8 \text { points } \\
n & =40\end{aligned}$ & $\mathrm{n}=47=67.5 \%$ \\
\hline $\begin{array}{c}\text { semi-mature }=9-11 \text { points } \\
n=217\end{array}$ & $n=69=31.8 \%$ \\
\hline $\begin{array}{c}\text { mature } \geqslant 12 \text { points } \\
n=196\end{array}$ & $\mathrm{n}=48=24.4 \%$ \\
\hline
\end{tabular}

Tab. IV. Portio index in maturity groups and post partum condition of the infants $(n=453)$. Distribution of the APGAR scores.

\begin{tabular}{llcc}
\hline $\begin{array}{l}\text { APGAR } \\
\text { Portio maturity }\end{array}$ & $0-4$ & $5-7$ & $8-10$ \\
$\begin{array}{l}\mathrm{n}=8 \text { points } \\
\mathrm{n}=40\end{array}$ & - & $5 \%$ & $95 \%$ \\
$\begin{array}{l}9-11 \text { points } \\
\mathrm{n}=217\end{array}$ & - & $2.3 \%$ & $97.6 \%$ \\
$\begin{array}{l}\geqslant 12 \text { points } \\
\mathrm{n}=196\end{array}$ & - & $1.5 \%$ & $98.5 \%$ \\
\hline
\end{tabular}

\section{Discussion}

The evaluation of results emerging from this study clearly point out how important cervix maturity is as a selection criterion for the decision to induct labor. This fact, fully accepted for first-bearers should also not be overlooked - as has been the case lately $[7,11,12]$ - in patients having given birth before. For exactly in the case of patients having given birth for a second time or more, an almost linear negative correlation can be drawn between the duration of the birth and the portioindex (Tab. V). The strong negative correlation as described on page 6 - is not a particular induction selection but rather a generally accepted fact.

Therefore in birth inductions which are decided upon taking into account only the maturation of the fetus or its gestational age, disregarding cervix maturity, in most cases one can reckon with a long duration of the birth. However, it is now an accep-
Tab. V. Portio index in maturity groups and post partum condition of the infants $(n=401)$. Distribution of the $\mathrm{pH}_{\mathrm{NA}}{ }^{-v a l u e s}$.

\begin{tabular}{|c|c|c|c|}
\hline $\begin{array}{l}\mathrm{pH} \\
\text { Portio maturity }\end{array}$ & 7,19 & $7,2-7,29$ & 7,3 \\
\hline $\begin{aligned} & \leqslant 8 \text { points } \\
n & =29\end{aligned}$ & $5.2 \%$ & $41.3 \%$ & $53.5 \%$ \\
\hline $\begin{array}{l}9-11 \text { points } \\
n=198\end{array}$ & - & $26.2 \%$ & $73.8 \%$ \\
\hline $\begin{aligned} & \geqslant 12 \text { points } \\
\mathrm{n} & =174\end{aligned}$ & - & $22.9 \%$ & $77.1 \%$ \\
\hline
\end{tabular}

ted fact that a shortening of the birth duration helps to reduce the danger of asphyxia and infant mortality [4] . A prolonged birth should therefore be avoided.

When a medical indication makes it necessary to end the pregnancy, it will often not be possible to wait for the cervix to be mature. In such cases other factors determine when the induction should start. However in a scheduled delivery, which should minimize the danger to mother and infant, this important fact should not be overlooked. In non-risk pregnancies therefore the indication to terminate the pregnancy at an optimal time $[2,5,6,9]$ should depend entirely on the birth tendency of the portio, whereby in particular the dilatation of the cervix plays an important part as a prognostic criterion for the duration of the birth.

This fact is supported by the following points: In our examinations it has been shown that the frequency of operative deliveries particularly caesareans, and also maternal morbidity decreases in accordance with the birth-tendency of the portio. As far as the infant is concerned the best post partum APGAR and $\mathrm{pH}$ scores are achieved when the birth is induced, the cervix being mature. The results given here clearly demonstrate that the pelvic score must be regarded as a selection criterion for an induction decision. When a decision has been made to induce the birth, the maturity of the infant has been established and the cervix is ready, then very very good results as to the duration of the birth, the operation frequency and the condition of the infant post partum can be expected. 
Summary

Recently some obstetricians have repudiated the importance of cervical maturity for the success of birth induction in patients having given birth before. They are of the opinion that a woman who has already given birth to a child will not expect to have any difficulties concerning the portio. This view clearly contradicts our experience collected from 2000 birth inductions. The aim of this study therefore is to prove - through a series of examinations - whether and for which reasons the cervical maturity must be taken into consideration when inducing the birth. In this study all patients were registered who had a scheduled delivery or an induction for medical indications, during the period from January 1 st 1976 to March 31 st 1978 at the MARTIN-LUTHER HOSPITAL in Berlin. After deducting those births were labor began spontaneously, 1315 patients were included in the statistical calculation, of these 680 were giving birth for the first time, and 635 had given birth before. Before each induction, the cervical maturity was prospectively determined always by the same examiner. In a first study which included 516 first-bearers and 453 who had given birth before, we used the BISHOP score modified according to MENNEKING [10], and in a second study with 164 first-bearers and 182 having given birth before, the cervical maturity was judged with a gradually refined portio index (Tabs. I + II). The results were retrospectively considered in relation to the duration of the birth, the frequency of operation and the condition of the infants post partum. A strong negative correlation occurred between the portio score and the duration of the birth. In first-bearers $r$ was equal to -0.97 , and in those having given birth before, $r=-0.95$. This very close relationship emerged even more clearly in the refined findings in the group considered. Here there was a result of $r=-0.9933$ in those having given birth before, and $r=-0.9612$ in first bearers. In this process the strong negative correlation was graphically represented with the help of regression lines (Fig. 2).

In order to see whether a particular parameter has a special influence, the single parameters of the portio index were correlated in turn with the duration of the

Keywords: Cervix maturity, induction of labor, pelvic score. birth. The evaluations showed that the dilatation of the cervix influences the complete portio index overproportionally, and the station of the presenting part influences it underproportionally. (Fig. 3). As the strong negative correlation between duration of the birth and the portio index can be a function of a particular induction selection and also a generally valid fact, we examined whether the distribution of frequency of the portio indices deviated from a normal distribution. For first bearers and those having given birth before, there emerged a good adjustment according to LIENERT to a GAUSS distribution with an error probability of $50 \%$ (Figs. $4 \mathrm{a}+\mathrm{b}$ ). So it can be assumed that the strong negative correlation between portio index and duration of the birth is a generally valid fact.

In order to recognize a dependency of the frequency of operation from the birth tendency of the portio,scores modified according to MENNEKING [10] were divided qualitatively in 3 groups (Tab. III) and the frequency of operative births in the 3 groups was noted. In the group where the induction took place with mature cervix, the frequency of operation was the lowest. When one compared the condition post partum of infants in the three groups, then one can see from the results that infants induced with mature portio have better APGAR and $\mathrm{pH}$ values.

The evaluation emerging from results achieved clearly proves how very important cervix maturity is, as a selection criterion for induction decisions particularly in those having given birth before. In as far as a medical indication makes it necessary to end a pregnancy, it is frequently not possible to wait until the cervix is mature. However in the scheduled delivery which should minimize the dangers to mother and infant this important fact should not remain unobserved. When a decision has been made to induce the birth, the maturity of the infant has been established, and the cervix is ready, then very good results as to the duration of the birth, the operation frequency and the condition of the infant post partum can be expected.

\section{Zusammenfassung}

Gefahren bei Geburtseinleitungen ohne Beachtung der Zervixreife.

In jüngster Zeit haben einige Geburtshelfer $[6,10]$ die Bedeutung der Zervixreife für den Erfolg einer Geburtseinleitung bei Mehrgebärenden in Abrede gestellt. Sie sind der Meinung, daß eine Frau, die bereits ein Kind geboren hat, keine Schwierigkeiten von Seiten der Portio zu erwarten habe. Diese Ansicht steht im deutlichen Widerspruch $\mathrm{zu}$ unseren eigenen, an 2000 Geburtseinleitungen gesammelten Erfahrungen. Ziel dieser Arbeit ist es daher, anhand einer prospektiven Untersuchungsreihe zu prüfen, ob und aus welchen Gründen die Zervixreife bei Geburtseinleitungen Beachtung finden muß. In dieser Studie sind alle Patientinnen registriert, bei denen in dem Zeitraum vom 1.1.1976 bis zum 31.3.1978 am Martin-Luther-
Krankenhaus Berlin eine programmierte Geburt oder eine Einleitung aus medizinischer Indikation durchgeführt wurde. Für die statistische Auswertung konnten nach Abzug der Geburten mit spontanem Wehenbeginn 1315 Patientinnen berücksichtigt werden und zwar 680 Erst- und 635 Mehrgebärende. Vor jeder Einleitung wurde prospektiv die Zervixreife von immer demselben Untersucher bestimmt. In einer ersten Studie, die 516 Erst- und 453 Mehrgebärende umfaßte, kam dabei der nach MENNEKING [10] modifizierte BISHOP-Score zur Anwendung, in einer zweiten Studie an 164 Erst- und 182 Mehrparae wurde die Zervixreife mit einem graduell verfeinerten Portioindex (Tab. I+II beurteilt. Die Ergebnisse wurden dann retrospektiv in Beziehung zur Geburtsdauer, der Operationsfrequenz und dem postpartualen 
Zustand der Kinder gesetzt. Zwischen Portioscore und Geburtsdauer errechnete sich eine starke negative Korrelation. Bei der Erstpara ergab sich für $r=-0.97$, bei der Mehrpara für $r=-0,95$ (Abb. 1). Diese sehr enge Beziehung trat in dem nach dem verfeinerten Befundschema beurteilten Kollektiv noch deutlicher hervor. Hier errechnete sich bei den Mehrgebärenden für $\mathrm{r}$ ein Wert von $-0,9933$. Bei den Erstparae betrug $r=-0.9612$. Bei diesem Vorgehen wurde die starke negative Korrelation mit Hilfe der Regressionsgeraden graphisch dargestellt (Abb. 2).

Um zu sehen, ob ein bestimmter Parameter einen besonderen Einfluß ausübt, wurden die Einzelparameter des Portioindex der Reihe nach mit der Geburtsdauer korreliert. Die Berechnungen ergaben, daß die MM-Weite überproportional, der Höhenstand des vorangehenden Teils unterproportional den Gesamtportioindex beeinflussen (Abb. 3).

Da die starke negative Korrelation zwischen Geburtsdauer und Portioindex eine Funktion einer bestimmten Einleitungsselektion, aber auch eine allgemein gültige Tatsache sein kann, wurde untersucht, ob die Häufigkeitsverteilung der Portioindizes von einer Normalverteilung abweicht. Für Erst- und Mehrparae fand sich bei einer Irrtumswahrscheinlichkeit von $50 \%$ eine nach LIENERT gute Anpassung an eine GAUSS'sche Verteilung. (Abb. 4 $a+b)$. Somit darf angenommen werden, daß die starke

Schlüsselwörter: Geburtseinleitung, Portio-Index, Zervixreife negative Korrelation zwischen Portioindex und Geburtsdauer eine allgemein gültige Tatsache ist.

Um eine Abhängigkeit der Operationsfrequenz von der Geburtsbereitschaft der Portio erkennen zu können, wurde der nach MENNEKING [10] modifizierte Portioscore qualitativ in 3 Gruppen unterteilt (Tab. III) und die Frequenz der operativen Entbindungen in den 3 Gruppen ermittelt. In der Gruppe der Einleitungen mit reifer Zervix lag die Operationsfrequenz am niedrigsten. Vergleicht man den postpartualen Zustand der Kinder in den 3 Gruppen untereinander, so läßt sich aus den Ergebnissen ablesen, daß die Kinder nach Einleitungen bei reifer Portio die günstigsten APGAR- und pH-Werte aufwiesen (Tab. IV+V).

Die Auswertung der in dieser Studie gewonnenen Ergebnisse veranschaulicht deutlich, wie groß die Bedeutung der Zervisreife als Auswahlkriterium für eine Einleitungsentscheidung insbesondere bei der Mehrpara ist. Sofern eine medizinische Indikation die Schwangerschaftsbeendigung erforderlich macht, wird es häufig nicht möglich sein, die Reifung der Zervix abzuwarten. Bei der programmierten Geburt aber, die eine Gefährdung von Mutter und Kind minimieren soll, darf diese wichtige Erkenntnis nicht unbeachtet bleiben. Wenn bei nachgewiesener Reife des Kindes eine Geburt eingeleitet werden soll, so sind bei geburtsbereiter Zervix hinsichtlich der Geburtsdauer, der Operationsfrequenz und des postpartualen Zustandes des Kindes die günstigsten Resultate zu erwarten.

\section{Résumé}

Dangers de l'induction du travail sans prise en considération de la maturité cervicale.

Dans les derniers temps certains obstétriciens [6] 10t ont mis en doute l'importance de la maturité cervicale quant à la réussite du travail induit chez la multipare. Ils défendent l'opinion selon laquelle une patiente qui a déja accouché d'un enfant n'aurait pas de fifficultés à attendre du côté de son col. Ce point de vue se trouve être en contradiction avec notre expérience que nous avons pu rassembler au cours de 2000 inductions du travail. C'est pourquoi le but de ce travail est de déterminer, au moyen d'une série prospective d'étude, si oui et pour quelles raisons la maturité cervicale doit être considérée lors des déclanchements du travail' Nous avons enregistré dans cette étude toutes les patientes ayant bénéficié d'un accouchement réglé ou d'un déclanchement du travail d'indication médicale entre le 1.1.1976 et le 31.3. 1978 à la MATERNITE MARTIN-LUTHER de Berlin. Après exclusion des accouchements à début spontané du travail, nous avons retenu en vue de l'analyse statistique 1315 patientes, soit 680 primipares et 635 multipares. La maturité cervicale a été appréciée avant chaque déclenchement toujours par le même examinateur. Dans une première étude comprenant 516 primipares et 453 multipares nous avons utilisé le score de BISHOP modifié selon MENNEKING [10]; dans une deuxième étude chez 164 primipares et 182 multipares c'est un index cervical graduellement affiné (Tabs' I+II) qui a été pris en considération. Les résultats ont alors été mis en relation rétrospectivement avec la durée de l.accouchement, la fréquence des interventions obstétricales et l'état du nouveau-né à la naissance. Une relation négative très étroite a été mise en évidence entre le score cervical et la durée de l'accouchement. Chez la primipare nous notons un $r=-0,97$ et chez la multipare un $r$ « 0,95' Dans le schéma affiné d'appréciation cette relation étroite était encore plus manifeste (Fig. 1). Ici l'on calculait un $r=-0,9933 \mathrm{chez}$ les multipares et un $r=-0,9612 \mathrm{chez}$ les primipares. Cette correlation fortement négative a été représentée graphiquement à l'aide des droites de régréssion. (Fig. 2).

Afin de verifier si un quelconque paramètre exerce une influence particulière, les nous avons mis en relation les paramètres individuels du score cervical avec la durée de l'accouchement. Les calculs ont montré une influence surproportionelle de l'ouverture du col et une influence infraproportionnelle du degré d'engagement de la presentation ceci par rapport á l'influence du score cervical pris dans son ensemble (Fig. 3).

Etant donné que la corrélation fortement négative entre durée de l'accouchement et l'index cervical peut être le fait d'une certaine sélection des déclenchements, mais aussi un fait valable en général, nous avons étudié si la distribution de fréquence des indices cervicaux présentait une déviation par rapport à la distribution normale. Aussi bien pous les primipares que pour les multipares l'on observe, avec une probabilité d'érreur de $50 \%$ une bonne conformité selon LIENERT avec une distribu- 
tion selon une courbe de GAUSS. (Fig. $4 a+b$ ). Ainsi l'on peut admettre, que l'étroite Relation négative entre score cervical et durée d'accouchement est un fait généralement valable.

Afin de reconnaître une dépendance de la fréquence des interventions de la maturité cervicale obstétricale, nous avons groupé qualitativement en 3 le score cervical modifié selon MENNEKING (Tab. III) [10] et nous avons analysé la fréquence des accouchement instrumentaux selon 3 groupes. Dans le groupe des déclenchements avec col obstétricalement mur cette fréquence était la moindre. Si l'on compare l'état des enfants à la naissance, l'on peut observer à partir de nos résultats, que les enfants nés après déclenchement à col mur présentent les valeurs d'APGAR et de $\mathrm{pH}$ les plus favorables.
L'appréciation des résultats de cette étude concrétise clairement la grande importence de la maturité cervicale en tant que critère de sélection en vue du déclenchement, en particulier chez la multipare. D'es qu'une raison médicale impose l'achèvement de la grossesse, il est souvent impossible d'attendre la maturité cervicale. Cependant pour ce qui est des accouchements réglés, qui doivent réduire au minimum les risques materncls et foetaux, ce fait important ne doit pas être perdu de vue. Quand la maturité foetale est atteinte et quel accouchement doit être déclenchá, l.on peut s.attendre á de bons résultats quant á la durée du travail, de la fréquence des interventions obstétricales et de l'état postpartal de 1 enfant. lorsque la maturité cervicale est atteinte.

Mots-clés: Déclenchement du travail, index cervical, maturité cervicalc.

\section{Bibliography}

[1] BISHOP, E. H.: Pelvic scoring for elective induction of labor. Obstet. Gynec. 24 (1964) 266.

[2] BOLTE, A., K.H.BREUKER, W. HAASE, J. STILLE: Vor- und Nachteile der terminierten Geburt. Geburtsh. u. Frauenheilk. 220 (1976) 220.

[3] BRÄUTIGAM, H. H., P. WOLDT: Auswahlkriterien. In: HILlEMANNS, H. G., H. STEINER (eds.): Die programmierte Geburt. 1. Freiburger Kolloquium 1976. Thieme, Sutttgart 1978.

[4] HellmanN, L. M., H. PRYSTOSWKY: The duration of the second stage of labor. Amer. J. Obstet. Gynec. 63 (1952) 1223.

[5] HILLEMANNS, H. G., F. MROSS, H. SCHNELLER: Die programmierte Geburt. In: DUDENHAUSEN, J. W., E. SALING, E. SCHMIDT (eds.): Perinatale Medizin, Bd. VI. Thieme, Stuttgart 1975.

[6] JUNG, H., G. LAMBERTI, R. AUSTERMANN, P. CLOSS: Die programmierte Geburt. In: DUDENHAUSEN, J. W., E. SAling (eds.): Perinatale Medizin, Bd. V. Thieme, Stuttgart 1974.
[7] JUNG, H.: Methoden der Geburtseinleitung bei programmierter Geburt. In: HILlEMANNS, H. G., H. STEINER (eds.): Die programmierte Geburt. 1. Freiburg Kolloquium 1976. Thieme, Stuttgart 1978.

[8] MARTIUS, G.: Terminierung der Entbindung und perinatale Sterblichkeit - Erfahrungen mit 1875 programmierten Geburten. Dtsch. Med. Wschr. 101 (1976) 489.

[9] MARTIUS, G.: Lehrbuch der Geburtshilfe. Thieme, Stuttgart 1977.

[10] MENNKING, U.: Die kombinierte Geburtseinleitung. Dissertation 1973.

[11] MUTKE, H. G.: Vorbedingungen zur programmierten Geburt. In: HILLEMANNS, H. G., H. STEINER (eds.): Die programmierte Geburt. 1. Freiburger Kolloquium 1976. Thieme, Stuttgart 1978.

[12] MUTKE, H. G.: Die programmierte Beendigung der Schwangerschaft und die terminierte Geburt. Dtsch. Ärzteblatt 74 (1977) 1 .

Received April 4, 1979. Revised September 28, 1979. Accepted October 16, 1979

Dr. med. K. Goeschen Arbeitsgruppe für Perinatale Medizin Mariendorfer Weg 28-38

D-1000 Berlin 44 